\title{
Authors' reply - anaphylactic shock with methylprednisolone, Kounis syndrome and Hypersitivity to corticosteroids: a clinical paradox
}

\author{
F. Porcaro ${ }^{1 *}$ (D, M. G. Paglietti ${ }^{1}$, A. Diamanti ${ }^{2}$, F. Petreschi ${ }^{1}$, A. Schiavino ${ }^{1}$, V. Negro ${ }^{1}$, V. Pecora ${ }^{3}$, A. Fiocchi ${ }^{3}$ and \\ R. Cutrera ${ }^{1}$
}

\begin{abstract}
In our letter, we comment the paper of Kounis et al., that highlights a poor-known clinical entity determined by systemic use of corticosteroids, the so-called "Kounis syndrome type I". We appreciated and shared the intent of Authors to treat the important issue of high risk of adverse drug reaction in patients with atopic diathesis and we confirm the need to administer corticosteroids with caution in patients suffering from allergic disease.
\end{abstract}

Keywords: Anaphylactic shock, Corticosteroids, Kounis syndrome

\section{Letter to the Editor}

Dear Editor,

in their comment to our case report on a one-year-old male presenting anaphylactic shock episodes triggered by intravenous administration of methylprednisolone sodium succinatum, Kounis et al., highlighted a poor-known clinical entity determined by systemic use of corticosteroids (the so-called "Kounis syndrome type I") [1]. Authors have furtherly raised the important issue of high risk of adverse drug reaction in patients with atopic diathesis.

We thank the Authors for having provided a comprehensive overview on pharmacodynamic profile of corticosteroids and the main mechanisms underpinning the most frequent adverse reactions to these common-used drugs.

As already exhaustively reported, two type of hypersensitivity reactions to systemic steroid administration should be mainly considered: immediate (IgE-mediated) and delayed ( $\mathrm{T}$ cell-mediated) reactions [2].

Because of the risk of life-threatening reactions, to investigate mechanisms underlying immediate steroid allergic reactions is of great interest into scientific community.

\footnotetext{
* Correspondence: federica.porcaro@opbg.net

${ }^{1}$ Respiratory Unit, Academic Department of Pediatrics, Bambino Gesù

Children's Hospital, IRCCS, Piazza di Sant'Onofrio 4, 00165 Rome, Italy

Full list of author information is available at the end of the article
}

The native drug-molecule or a drug metabolite (hapten) may act as an allergen. Moreover, esters used to create soluble injectable preparations (sodium succinate and sodium phosphate) can, sometimes, justify the allergic reactions rather than the glucocorticoid itself. Finally, glucocorticoid preparations may contain preservatives and excipients (e.g. lactose, carboxymethylcellulose, polyethylene glycol, hexylene glycol) to which sensitized patients can react [2].

In our case report, the anaphylactic shock occurred in a cow's milk allergic patient, after the administration of systemic steroid formulation containing lactose and cow's milk proteins traces. Although the first allergic reaction was attributed to the antibiotic treatment, the next episode clarified the cause-effect relationship allowing the diagnosis.

The delayed diagnosis of immediate allergic reaction to steroid is another important issue. In fact, patients typically receive glucocorticoids for several clinical conditions (asthma, anaphylaxis or shock) which present signs and symptoms similar to those of allergic reactions. Therefore, it can be difficult to distinguish a progressively worsening of medical condition from a superimposed allergic reaction to a glucocorticoid.

(c) The Author(s). 2019 Open Access This article is distributed under the terms of the Creative Commons Attribution 4.0 International License (http://creativecommons.org/licenses/by/4.0/), which permits unrestricted use, distribution, and reproduction in any medium, provided you give appropriate credit to the original author(s) and the source, provide a link to the Creative Commons license, and indicate if changes were made. The Creative Commons Public Domain Dedication waiver (http://creativecommons.org/publicdomain/zero/1.0/) applies to the data made available in this article, unless otherwise stated. 
In conclusion, we agree with the Authors on the need to administer corticosteroids with caution in patients suffering from atopic disease.

\section{Acknowledgements}

Not available.

\section{Funding}

None.

Availability of data and materials

Data sharing not applicable to this article as no datasets were generated or analyzed during the current study.

\section{Authors' contributions}

Federica Porcaro and VP managed the patient and wrote the first draft of the manuscript. MGP, AD, FP, AS, VN managed the patient and critically reviewed the manuscript. AF, RC designed the study and critically reviewed the manuscript. All authors read and approved the final manuscript.

\section{Ethics approval and consent to participate}

Not required.

\section{Consent for publication}

Not required.

\section{Competing interests}

The authors declare that they have no competing interests.

\section{Publisher's Note}

Springer Nature remains neutral with regard to jurisdictional claims in published maps and institutional affiliations.

\section{Author details}

${ }^{1}$ Respiratory Unit, Academic Department of Pediatrics, Bambino Gesù Children's Hospital, IRCCS, Piazza di Sant'Onofrio 4, 00165 Rome, Italy.

${ }^{2}$ Artificial Nutrition Unit, Bambino Gesù Children's Hospital, IRCCS, Rome, Italy.

${ }^{3}$ Division of Allergy, Academic Department of Pediatrics, Bambino Gesù

Children's Hospital, IRCCS, Rome, Italy.

Received: 15 December 2018 Accepted: 27 December 2018

Published online: 07 January 2019

\section{References}

1. Kounis NG, Koniari I, Soufras GD, Chourdakis E. Anaphylactic shock with methylprednisolone, Kounis syndrome and hypersensitivity to corticosteroids: a clinical paradox. Ital J Pediatr. 2018;44:143.

2. Otani IM, Banerii A. Immediate and delayed hypersensitivity reactions to corticosteroids: evaluation and management. Curr Allergy Asthma Rep. 2016;16(3):18.

Ready to submit your research? Choose BMC and benefit from:
- fast, convenient online submission
- thorough peer review by experienced researchers in your field
- rapid publication on acceptance
- support for research data, including large and complex data types
- gold Open Access which fosters wider collaboration and increased citations
- maximum visibility for your research: over 100M website views per year
At BMC, research is always in progress.
Learn more biomedcentral.com/submissions

